Available online at GSC Online Press Directory

GSC Biological and Pharmaceutical Sciences

e-ISSN: 2581-3250, CODEN (USA): GBPSC2

Journal homepage: https://www.gsconlinepress.com/journals/gscbps

(RESEARCH ARTICLE)

\title{
Analysis of pesticide residues in carrot retailed in vegetable markets in five districts of Karnataka, India
}

\author{
Ananda Gowda ${ }^{1}$ SR Kesava Reddy A 2 and Ramesh HL 1,* \\ ${ }^{1}$ Visveswarapura College of science, K.R.Road, Bangalore-56000, India. \\ ${ }^{2}$ KGF First Grade College, Oorgaum, KGF, Karnataka 563120, India.
}

Publication history: Received on 13 February 2020; revised on 24 February 2020; accepted on 28 February 2020

Article DOI: https://doi.org/10.30574/gscbps.2020.10.3.0041

\begin{abstract}
Carrot Daucus carota is a root vegetable, biennial plant in the umbellifer family Apiaceae and the roots contain alpha and beta-carotene and are a good source of vitamin $\mathrm{K}$ and vitamin B6. Pesticide residues in carrot samples of five districts viz., Bangalore Rural, Bangalore Urban, Chickballapura, Kolar and Ramanagara were analysed using gas chromatographic technique equipped with Electron Capture Detector (ECD) and Flame Thermo ionic Detector (FTD) for different pesticide residues of organophosphate, organochlorine, synthetic pyrethroids and carbamates. Acephate contamination accounted 25\% in Bangalore rural, 37.5\% each in Bangalore urban, Chikkaballapura and Ramanagara districts. Chlorpyriphos residue above MRL of $0.2 \mathrm{mg} / \mathrm{kg}$ noticed in all the districts except Bangalore Urban. Dichlorvos contamination hardly crossed the limit and the mean concentration of fenvalerate in different district in the order Bangalore Urban $>$ Kolar $>$ Chickballapura $>$ Ramanagara= Bangalore Rural. Cyfluthrin- $\beta$ is not detected in any districts and the concentration of monocrotophos, cyhalothrin- $\lambda$, cypermethrin and deltamethrin were found below the permissible limit in all the places.
\end{abstract}

Keywords: Carrot; Pesticide Residue; Karnataka; Gas chromotograph

\section{Introduction}

In India, DDT and BHC are partially banned, but still very much used in agriculture and public health programs because of their wide spectrum of activity and low cost. It is suspected that most of our water bodies and soils are contaminated with these chemicals or with their degradation products [1]. Approximately, 30\% of Indian crop yield potential is being lost due to insects, diseases and weeds, which in terms of quantity accounts to 30MT of food. Available reports also indicate that loss of food grains is estimated to be $23 \%$ and $25 \%$ respectively due to insects and diseases [2]. Pesticides are one among the chemicals that were added to an agro-ecosystem and hence they are referred to as agrochemicals. [3] considered pesticides, fertilizers, hormones and growth regulators as agrochemicals. Pesticides have both physical and chemical characteristics which include solubility, adsorption, volatility and the potential for degradation. Some pesticides are highly soluble and readily dissolve in water and normally come with the water flow.

India is the second largest producer of vegetables in the world (ranks next to china) and accounts for about 12 per cent of world production of vegetables with the productivity of 15 tonnes/tonne/hectare which is quite low compared to other countries. The current production level is over 87.5 million tonnes and total area under vegetable cultivation is around 6.2mha [4]. In the world, India occupies first position in the production of cauliflower, brinjal and peas, second in onion and third in cabbage [5]. The increase in population and urbanization and the rising income have given great importance to the cultivation of vegetable crops [6].

\footnotetext{
* Corresponding author: Ramesh HL
} 
Pesticide residue is any specified substance on or in food, agricultural commodities, or animal feed resulting from the use of a pesticide. The term includes any derivative of a pesticide, such as conversion products, metabolites, reaction products, and impurities considered to be of toxicological significance. The term pesticide residue includes residues from unknown or unavoidable sources (e.g., environmental), as well as known uses of the chemical. The presence of residues in food, water and fodder is of concern to every human being. Pesticide residues mainly occur due to over usage and indiscriminate spraying on crops. Studies carried out by various institutions across the country indicate that $50-70$ per cent of vegetables are contaminated with insecticide residues and 11 per cent of these samples had residues above $\operatorname{MRL}[7,8]$.

The objectives of the present study are:

- Identify and assess the pesticide levels in the selected vegetables from the point view of safety to consumers.

- Comparing the observed residue levels with PFA and Codex Standards.

- Enumerate the most prevalent pesticides among three different chemical groups i.e., organochlorines (OC), organophosphorus (OP), and synthetic pyrethroids (SP) for guidance to farmers and policy makers for future use.

- Making appropriate recommendations to facilitate extension workers to adopt safe pesticide usage in crop cultivation

\section{Material and methods}

This deals with the description of the materials used, study area, sampling period, the sampling procedure adopted, the questionnaire survey and analytical tools and techniques employed. The present study was conducted during the year 2018-2019 in five districts of Karnataka. Field study was conducted to collect the information about various aspects of pesticide use and their safety. This information was used as the baseline data to investigate the residue level of the analyzed pesticides in vegetables.

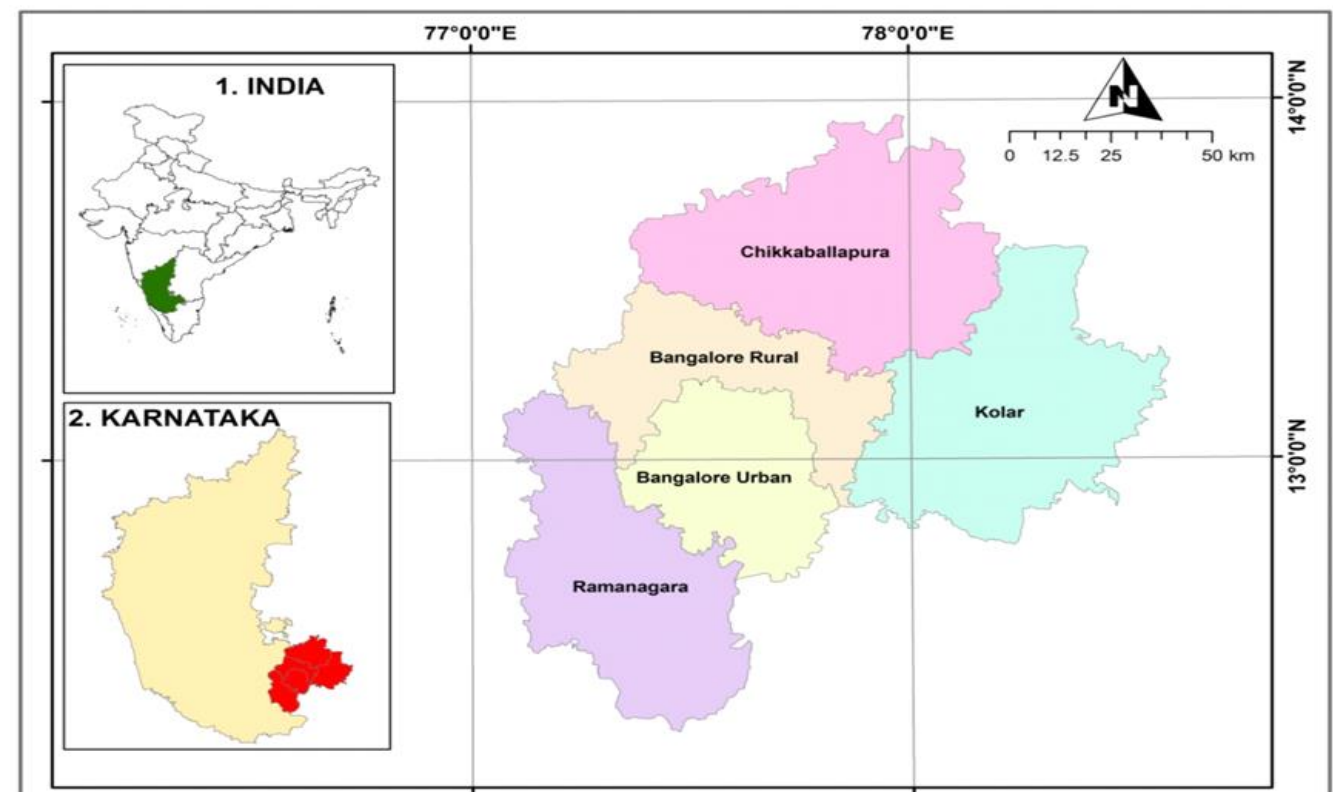

Figure 1 Location map of the study area

Karnataka State is situated in the west central part of peninsular India, geographically located between 11030 ' $\mathrm{N}$ to 180 $30^{\prime} \mathrm{N}$ latitudes and $740 \mathrm{E}$ to 78030 ' E longitude. The state covers an area of 191,976 square kilometers (74,122 sq mi) or $5.83 \%$ of the total geographical area of India. Five districts of Karnataka namely, Bangalore rural, Bangalore urban, Chikkaballapura, Kolar and Ramanagara (Figure.1) are presenting the hub of agricultural activities were selected as study areas for the determination of pesticide residues in vegetable samples. A sporadic information and data was collected from farmers with respect to use of different pesticides and harvesting period of vegetables and fruits in the 
study area. The sampling period covered the pre- and post- rainy seasons, coinciding with maximum harvest period of vegetable samples coming from different sources of agriculture in the region were procured randomly in the year 20182019.

\subsection{Standard solutions}

Pesticide standard stock solutions were procured from Indian Agricultural Research Institute (IARI), New Delhi. Working standard solutions containing a mixture of the analyte were prepared from the stock by appropriate solvent dilutions in n-hexane.

For standards preparation, the required amount of pesticide standards were mixed with required volume of n-hexane (HPLC grade).The stock solutions, 100ppm of each pesticide were prepared, labeled and stored in airtight clean bottles. From this, a single mix standard of $100 \mathrm{ppm}$ was prepared, which was diluted firstly to $10 \mathrm{ppm}$ and then to $1 \mathrm{ppm}$. The $1 \mathrm{ppm}$ mix standard was used to make the calibration standards of $0.01,0.5$ and $1.0 \mathrm{ppm}$. In this way, a series of calibration standards ranging from 1.0 to $0.01 \mathrm{ppm}$ was prepared. The single and mixed stock solutions were stored at $-5^{\circ} \mathrm{C}$ while, the calibration standards were made on the day of analysis. The calibration standards so prepared $(1 \mu \mathrm{l})$ were injected to GC and analyzed.

\subsection{Reagents}

All solvents like n-hexane, acetonitrile, petroleum ether and diethyl ether (HPLC grade) were procured from Sigma Aldrich Co., and were glass distilled before use. AR grade sodium chloride $(\mathrm{NaCl})$ and anhydrous sodium sulphate $\left(\mathrm{Na}_{2} \mathrm{SO}_{4}\right)$ was procured from HIMEDIA Pvt. Ltd., India. Before use, anhydrous sodium sulphate $\left(\mathrm{Na}_{2} \mathrm{SO}_{4}\right)$ was purified with acetone and heated for $4 \mathrm{hr}$ at $400^{\circ} \mathrm{C}$ in a muffle furnace to remove possible phthalate impurities. Florosil (60-100 mesh) purchased from Merck India limited was activated at $450^{\circ} \mathrm{C}$ and reheated at $130^{\circ} \mathrm{C}$ for $5 \mathrm{hr}$ before use.

\subsection{Pesticide analysis}

During this investigation, a residue of insecticide in carrot was monitored in 50 vegetable samples from five districts of Karnataka using Gas Chromatograph with ECD and FTD (Shimadzu make, Model GC-2010). Preparation of the samples and determination of insecticide residues was based on the method described by [9].

\subsection{Extraction}

In the present study, only the edible parts of vegetable samples $(1.0 \mathrm{~kg})$ were chopped and $50 \mathrm{~g}$ of samples were extracted in a warring blender with $100 \mathrm{ml}$ acetonitrile for $2-3 \mathrm{~min}$. The solvent was filtered through a Buchner funnel. The fruit residue was again subjected to extraction with $50 \mathrm{ml}$ acetonitrile two more times. The extracts were evaporated under vacuum to about $5 \mathrm{ml}$ and then transferred to a separator funnel of capacity $1000 \mathrm{ml} .600 \mathrm{ml}$ of $5 \%$ sodium chloride was added and the extract was exchanged into petroleum ether layer by liquid-liquid partitioning thrice $(100 \mathrm{ml}, 2 \times$ $50 \mathrm{ml})$. The extract was then passed through a layer of sodium sulfate $(5 \mathrm{~g})$ and evaporated to dryness in a rotary evaporator at a temperature below $40^{\circ} \mathrm{C}$.

\subsection{Clean up}

Glass column $(60 \mathrm{~cm}$ length $\times 2.0 \mathrm{~cm}$ I.D) was packed with a mixture of florisil $(10 \mathrm{~g})$, anhydrous sodium sulphate $(10 \mathrm{~g})$ and activated charcoal $(0.2 \mathrm{~g})$ supported on a cotton plug was used for cleanup and the sample was wetted with $50 \mathrm{ml}$ petroleum ether. Sample slurry prepared using petroleum etherwas transferred to the column. The glass beaker containing extract was rinsed with acetone and was transferred to the column, which was allowed to stand for $45 \mathrm{~min}$. Subsequently, the petroleum ether present in the column was eluted drop-wise $(5 \mathrm{ml} / \mathrm{min})$. When about $5 \mathrm{ml}$ petroleum ether remained on the surface of the adsorbent, the extract was eluted with $200 \mathrm{ml}$ each of freshly prepared $6 \%$ solvent mixture (diethyl ether in petroleum ether), 15\% solvent mixture (diethyl ether in petroleum ether) and 50\% solvent mixture successively. The eluents were concentrated to dryness in a rotary evaporator under vacuum and diluted to $10 \mathrm{ml}$ with $\mathrm{n}$-hexane for further analysis. From the dissolved residues, $1 \mu \mathrm{l}$ was injected to gas chromatograph and peak areas were compared with those obtained from similar injections of standards.

\subsection{Pesticide residue analysis}

The pesticide residue analysis was performed on Gas Chromatograph GC-2010 (Shimadzu make) equipped with ECD (Electron Capture Detector) and FTD (Flame Thermionic Detector). A fused silica capillary column (BP5- 5\% Phenyl, 95\% Dimethylpolysiloxane) was used for the analysis. 
Insecticides like organochlorines (OCs) and pyrethroids (SPs) were analyzed using ECD (63Ni) and a capillary column BP-5 $(60 \mathrm{~m} \times 0.25 \mathrm{~mm}$ I.D. $\times 0.25 \mu \mathrm{m}$ film thickness $)$ with split ratio $1: 10$. Nitrogen flow rate of $30 \mathrm{ml} / \mathrm{min}$, injection port temperature of $250^{\circ} \mathrm{C}$ and temperature of detector of $300^{\circ} \mathrm{C}$ and an injection volume of $1 \mu \mathrm{l}$ were the Gas - Liquid Chromatography (GLC) working conditions maintained during the analyses. The column temperature was initially maintained at $80^{\circ} \mathrm{C}$ for $5 \mathrm{~min}$ and then slowly increased to $260^{\circ} \mathrm{C}$ at the rate of $10^{\circ} \mathrm{C}$ per min for $5 \mathrm{~min}$ and finally increased to $290^{\circ} \mathrm{C}$ for $5 \mathrm{~min}$. In contrast, organophosphates (OPs) residues were analyzed with FTD and a split less capillary column DB-1 $(10 \mathrm{~m} \times 0.53 \mathrm{~mm}$ I.D. $\times 2.65 \mu \mathrm{m}$ film thickness $)$. The GLC working conditions maintained during the analyses were nitrogen flow rate of $60 \mathrm{ml} / \mathrm{min}$, hydrogen flow rate of $3 \mathrm{ml} / \mathrm{min}$, air flow rate of $150 \mathrm{ml} / \mathrm{min}$, injection port temperature of $280^{\circ} \mathrm{C}$, detector temperature of $300^{\circ} \mathrm{C}$ and an injection volume of $1 \mu \mathrm{l}$ with split ratio of $1: 10$. The column temperature was initially maintained at $180^{\circ} \mathrm{C}$ for $5 \mathrm{~min}$ and then gradually increased to $260^{\circ} \mathrm{C}$ for $5 \mathrm{~min}$.

\subsection{Estimation / Quantification of residues}

The carrier gas obtained from a steel gas cylinder passes through a flow regulator for the adjusted flow rate and enters into the sample injector. A little amount of the sample is introduced into the sample injector with the help of a hypodermic syringe. The sample injector is maintained at a temperature higher than the boiling point of the highest boiling component of sample in order to ensure rapid vaporization of the liquid samples. The carrier gas entering the sample injector sweeps off the vaporized sample and passes down the temperature programmed column. The components of the sample are distributed between the stationary and the mobile phases and pass down the column at different rates. This results in the separation of the components of the sample. The carrier gas with the separated components enters the detector, which measure the change in composition of the carrier gas as it passes through it. This change is amplified before it is fed into a recorder which drives the recording pen on a moving strip of paper and a chromatogram is obtained. Currently rapid instrumental methods are available for data processing and obtaining chromatograms in computer compatible formats.

The pesticide residue concentration was calculated using the equation,

Where

$$
\text { Residues value }(\mu \mathrm{g} / \mathrm{g})=\frac{A_{\mathrm{s}} \times V_{\text {std }} \times C_{\text {std }} \times D_{f}}{A_{\text {std }} \times V_{s} \times W_{s}}
$$

$A_{s}=$ peak area of sample injected $(\mathrm{mv})$

$A_{\text {std }}=$ peak area of standard injected (mv)

$\mathrm{V}_{\mathrm{s}}=$ volume of sample injected $(\mu \mathrm{l} / \mathrm{ml})$

$\mathrm{V}_{\mathrm{std}}=$ volume of standard injected $(\mu \mathrm{l} / \mathrm{ml})$

$\mathrm{C}_{\text {std }}=$ concentration of standard $(\mu \mathrm{g} / \mathrm{ml})$

$\mathrm{W}_{\mathrm{s}}=$ weight of sample taken $(\mathrm{g})$

$\mathrm{D}_{\mathrm{f}}=\operatorname{dilution}$ factor $(\mathrm{ml})$

\subsection{Fortification / Recovery studies}

The recovery studies for 3 replicates for each pesticide at three different fortification levels $(1.0,0.5 \mathrm{and} 0.01 \mathrm{mg} / \mathrm{kg})$ were carried out (Table-1). For this purpose, vegetable samples were spiked with $1 \mathrm{ml}$ of desired concentration of pesticide. Resulting samples were mixed and allowed to stand for $30 \mathrm{~min}$ before extraction and then processed separately as per the methodology described above. The amount of pesticide residues in vegetable samples were calculated by measuring peak areas from extracted current profiles and comparing with those obtained from matrixmatched standards of a concentration similar to that of samples. Spiked samples were calculated in the same way as regular samples [10-12].

\subsection{Calculation of Percentage Recovery}

The percentage recovery was calculated using the formula

$$
\% \text { Recovery }=\frac{\text { Amount recovered }}{\text { Amount spiked }} \times 100
$$

\subsection{Maximum Residue Levels (MRLs)}

Maximum residue levels may be defined as the maximum levels of pesticide residue present in or on a produce when pesticide used under supervision following good agricultural practices (GAP). According to Environmental Protection Agency (EPA), it is the concentration of a pesticide residue that can remain in food and feed products, or commodities. 
It is also known as 'pesticide residue limits' or tolerances, which are set to protect human from harmful levels of pesticides in food.

\subsection{Retention time (RT)}

Retention time is defined as the time elapsed from injection of sample into the chromatographic system until the highest concentration part of the peak is recorded in the chromatogram, which has diluted from the column (Table-2). In other words, it is length of time; a compound is retained on a chromatography column and is expressed in terms of minutes. The retention time on capillary column of Gas Chromatograph for various pesticide residues analyzed in the present study. It is evident from the results that the retention time for OCPs, OPPs and SPs ranged from 17.6 to 24.4, 11.6 to 22.4 and 30.6 to 34.5 mins respectively.

Table 1 Average recoveries and RSDs \% of different insecticides from the sample of carrot at fortification levels of 1.0 , $0.5,0.01 \mathrm{mg} / \mathrm{kg}$.

\begin{tabular}{|c|c|c|c|c|c|c|}
\hline \multirow[t]{3}{*}{$\begin{array}{l}\text { Sr. } \\
\text { No. }\end{array}$} & \multirow[t]{3}{*}{ 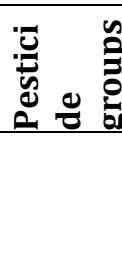 } & \multirow[t]{3}{*}{$\begin{array}{l}\text { Name of the } \\
\text { pesticide }\end{array}$} & \multicolumn{4}{|c|}{ Carrot $(n=3)$} \\
\hline & & & \multicolumn{3}{|c|}{ Level of fortification (mg/kg) } & \\
\hline & & & 0.01 & 1 & 0.5 & 0.01 \\
\hline 1 & \multirow{9}{*}{ :े } & Aldrin & $89.3(3.2)$ & $83.3(2.2)$ & $86.4(3.6)$ & $89.1(6.2)$ \\
\hline 2 & & Dieldrin & $84.2(3.7)$ & $84(3.3)$ & $95.5(2.3)$ & $86(5.5)$ \\
\hline 3 & & Endosulfan- $\alpha$ & $83.7(3.9)$ & $84.5(5)$ & $93.5(0.9)$ & $75.9(5.8)$ \\
\hline 4 & & Endosulfan- $\beta$ & $83.1(2.7)$ & $90(3.3)$ & $91.8(5.7)$ & $80.6(3.6)$ \\
\hline 5 & & $\begin{array}{l}\text { Endosulfan- } \\
\text { Sulphate }\end{array}$ & $86(3)$ & 86.1(3.3) & $96.2(1.4)$ & $88.5(5.6)$ \\
\hline 6 & & $\mathrm{HCH}-\alpha$ & $80.4(1.7)$ & $86.9(3.2)$ & $88.7(5.6)$ & $79.3(5.6)$ \\
\hline 7 & & $\mathrm{HCH}-\beta$ & $85.7(1.2)$ & $84.2(2.3)$ & $81.8(1.3)$ & $85.1(4.6)$ \\
\hline 8 & & $\mathrm{HCH}-\gamma$ & $85(1.7)$ & $85.3(3.7)$ & $93(2.5)$ & $75.9(1.6)$ \\
\hline 9 & & Heptachlor & $92.2(3.1)$ & $95.2(3)$ & $95.2(1.7)$ & $83.6(3.7)$ \\
\hline 10 & \multirow{6}{*}{$\frac{n}{0}$} & Acephate & $87.4(1.8)$ & $88.1(2.5)$ & $89.2(6.2)$ & \\
\hline 11 & & Chlorpyriphos & $86.6(1)$ & $84.8(1.7)$ & $94.6(3.4)$ & $84.5(5.4)$ \\
\hline 12 & & Dichlorvos & $94.4(2)$ & $89.9(1.9)$ & $92.2(2.3)$ & $92.4(4.8)$ \\
\hline 13 & & Monocrotophos & $87.2(2.1)$ & $92.7(2.8)$ & $88.4(3.6)$ & $88.4(1.6)$ \\
\hline 14 & & Phorate & 87.1(3.8) & $87.7(1.8)$ & 92.1(1..3) & $84.3(6.1)$ \\
\hline 15 & & Profenofos & $84.6(2.8)$ & $84.7(1.7)$ & $88.5(2.7)$ & $80.3(3.1)$ \\
\hline 16 & \multirow[b]{5}{*}{ 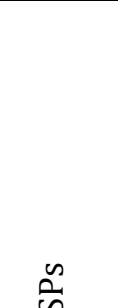 } & Cyfluthrin- $\beta$ & $84.1(3.3)$ & $83.8(3.5)$ & $86.9(5)$ & $83(3.7)$ \\
\hline 17 & & Cyhalothrin & $93.1(2.7)$ & $84.5(3.4)$ & $82.7(2.2)$ & $82.7(7.8)$ \\
\hline 18 & & Cypermethrin & $87.2(2.6)$ & $85.6(1.1)$ & $83.4(3.4)$ & $89.1(7.8)$ \\
\hline 19 & & Deltamethrin & $92.3(2.1)$ & $93.5(1.6)$ & $91.9(2)$ & 91.3(7) \\
\hline 20 & & Fenvalerate & $88.3(1.2)$ & $85.8(4.3)$ & $88.8(2.4)$ & $77(2.6)$ \\
\hline
\end{tabular}


Table 2 Retention time (RT) for various pesticide residues

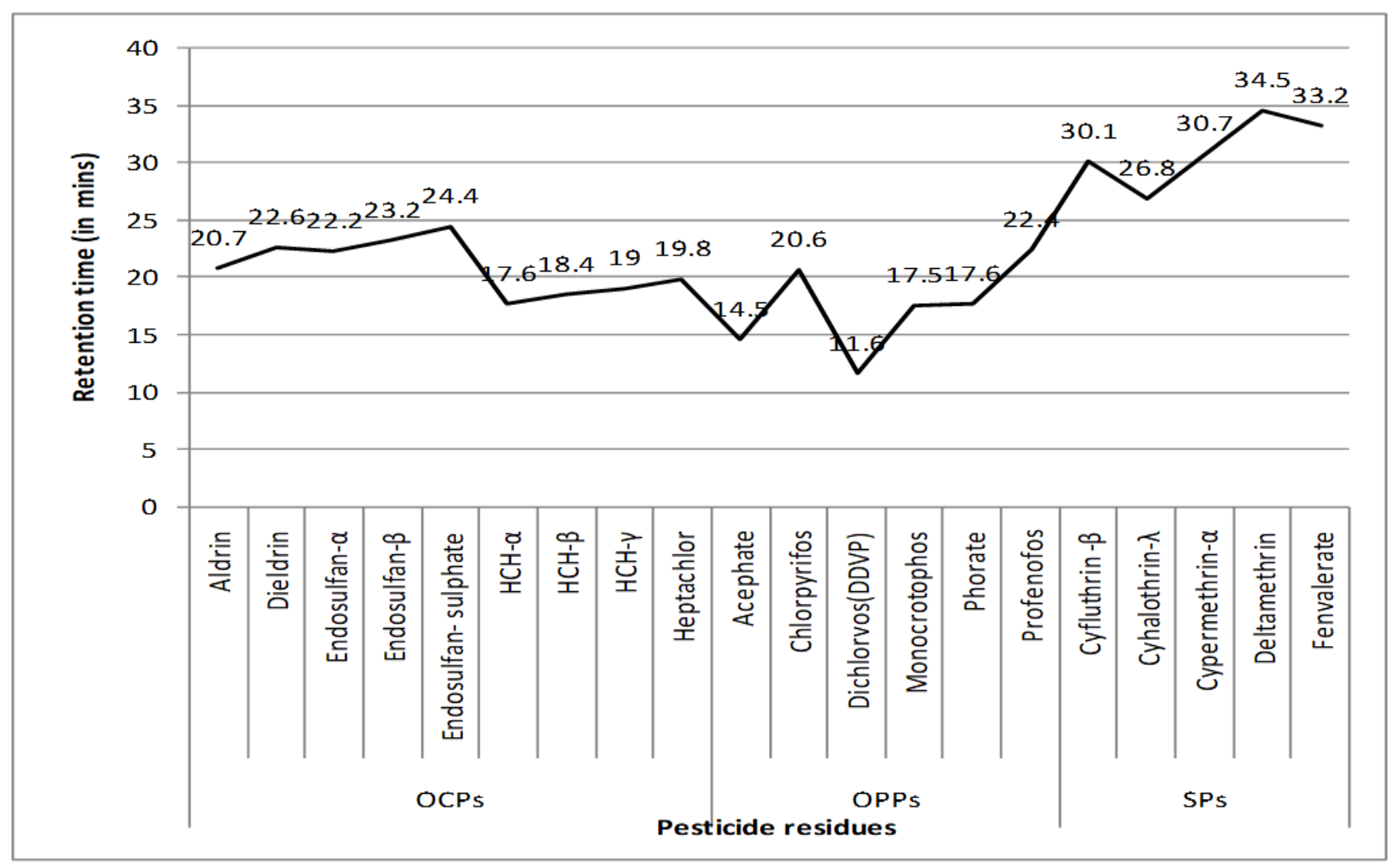


Table 3 Pesticide residues $(\mathrm{mg} / \mathrm{kg}$ ) in carrot samples

\begin{tabular}{|c|c|c|c|c|c|c|c|c|c|c|c|c|c|c|c|c|c|c|c|c|c|}
\hline \multirow{3}{*}{$\begin{array}{l}\text { Sl. } \\
\text { N } \\
\text { o. }\end{array}$} & \multirow{3}{*}{ Pesticides } & \multicolumn{20}{|c|}{ Residue range (mg/kg) } \\
\hline & & \multicolumn{4}{|c|}{ Bangalore rural (n=8) } & \multicolumn{4}{|c|}{ Bangalore urban (n=8) } & \multicolumn{4}{|c|}{ Chikkaballapura (n=8) } & \multicolumn{4}{|c|}{ Kolar (n=8) } & \multicolumn{4}{|c|}{ Ramanagara (n=8) } \\
\hline & & $\mathrm{a}(\mathrm{b})$ & $\min$ & $\max$ & $\begin{array}{l}\text { mea } \\
\mathrm{n}\end{array}$ & $\mathrm{a}(\mathrm{b})$ & $\min$ & $\max$ & $\begin{array}{l}\text { mea } \\
\mathrm{n}\end{array}$ & $a(b)$ & $\min$ & $\max$ & $\begin{array}{l}\text { mea } \\
\mathrm{n}\end{array}$ & $\mathrm{a}(\mathrm{b})$ & $\min$ & $\max$ & $\begin{array}{l}\text { mea } \\
\mathrm{n}\end{array}$ & $\mathrm{a}(\mathrm{b})$ & $\min$ & $\max$ & $\begin{array}{l}\text { mea } \\
\mathrm{n}\end{array}$ \\
\hline 1 & Acephate & $2(25)$ & $\begin{array}{l}0.0 \\
88\end{array}$ & $\begin{array}{l}0.0 \\
95\end{array}$ & $\begin{array}{l}0.0 \\
23\end{array}$ & $\begin{array}{l}3(37 . \\
5)\end{array}$ & $\begin{array}{l}0.0 \\
67\end{array}$ & $\begin{array}{l}0.2 \\
68\end{array}$ & $\begin{array}{l}0.0 \\
56\end{array}$ & $\begin{array}{l}3(37 . \\
5)\end{array}$ & $\begin{array}{l}0.1 \\
14 \\
\end{array}$ & $\begin{array}{l}0.2 \\
45\end{array}$ & $\begin{array}{l}0.0 \\
66\end{array}$ & BDL & BDL & BDL & BDL & $\begin{array}{l}3(37 . \\
5)\end{array}$ & $\begin{array}{l}0.1 \\
51\end{array}$ & $\begin{array}{l}0.3 \\
24 \\
\end{array}$ & $\begin{array}{l}0.0 \\
81\end{array}$ \\
\hline 2 & $\begin{array}{l}\text { Chlorpyrip } \\
\text { hos }\end{array}$ & $2(25)$ & $\begin{array}{l}0.0 \\
73\end{array}$ & $\begin{array}{l}0.0 \\
75\end{array}$ & $\begin{array}{l}0.0 \\
19\end{array}$ & $2(25)$ & $\begin{array}{l}0.0 \\
34\end{array}$ & $\begin{array}{l}0.3 \\
27\end{array}$ & $\begin{array}{l}0.0 \\
45\end{array}$ & BDL & BDL & BDL & BDL & $2(25)$ & $\begin{array}{l}0.0 \\
91\end{array}$ & $\begin{array}{l}0.0 \\
92\end{array}$ & $\begin{array}{l}0.0 \\
23\end{array}$ & BDL & BDL & BDL & BDL \\
\hline 3 & $\begin{array}{l}\text { Dichlorvos } \\
\text { (DDVP) }\end{array}$ & $\begin{array}{l}1(12 . \\
5)\end{array}$ & BDL & $\begin{array}{l}0.0 \\
13\end{array}$ & $\begin{array}{l}0.0 \\
02\end{array}$ & $\begin{array}{l}1(12 . \\
5)\end{array}$ & BDL & $\begin{array}{l}0.0 \\
27\end{array}$ & $\begin{array}{l}0.0 \\
03\end{array}$ & $\begin{array}{l}1(12 . \\
5)\end{array}$ & BDL & $\begin{array}{l}0.0 \\
11\end{array}$ & $\begin{array}{l}0.0 \\
01\end{array}$ & $\begin{array}{l}1(12 . \\
5)\end{array}$ & BDL & $\begin{array}{l}0.0 \\
14\end{array}$ & $\begin{array}{l}0.0 \\
02\end{array}$ & BDL & BDL & BDL & BDL \\
\hline 4 & $\begin{array}{l}\text { Monocroto } \\
\text { phos }\end{array}$ & BDL & BDL & BDL & BDL & BDL & BDL & BDL & BDL & BDL & BDL & BDL & BDL & BDL & BDL & BDL & BDL & BDL & BDL & BDL & BDL \\
\hline 5 & Phorate & $\begin{array}{l}3(37 . \\
5)\end{array}$ & $\begin{array}{l}0.0 \\
35\end{array}$ & $\begin{array}{l}0.0 \\
72\end{array}$ & $\begin{array}{l}0.0 \\
19\end{array}$ & $2(25)$ & $\begin{array}{l}0.0 \\
36\end{array}$ & $\begin{array}{l}0.0 \\
78\end{array}$ & $\begin{array}{l}0.0 \\
14\end{array}$ & $\begin{array}{l}3(37 . \\
5)\end{array}$ & $\begin{array}{l}0.0 \\
44\end{array}$ & $\begin{array}{l}0.0 \\
78\end{array}$ & $\begin{array}{l}0.0 \\
21\end{array}$ & $\begin{array}{l}3(37 . \\
5)\end{array}$ & $\begin{array}{l}0.0 \\
33\end{array}$ & $\begin{array}{l}0.0 \\
81\end{array}$ & $\begin{array}{l}0.0 \\
28\end{array}$ & $2(25)$ & $\begin{array}{l}0.0 \\
38\end{array}$ & $\begin{array}{l}0.0 \\
41\end{array}$ & $\begin{array}{l}0.0 \\
2\end{array}$ \\
\hline 6 & $\begin{array}{l}\text { Cyfluthrin- } \\
\beta\end{array}$ & BDL & BDL & BDL & BDL & $\begin{array}{l}1(12 . \\
5)\end{array}$ & BDL & $\begin{array}{l}0.0 \\
43\end{array}$ & $\begin{array}{l}0.0 \\
05\end{array}$ & BDL & BDL & BDL & BDL & BDL & BDL & BDL & BDL & BDL & BDL & BDL & BDL \\
\hline 7 & $\begin{array}{l}\text { Cyhalothrin } \\
-\lambda\end{array}$ & BDL & BDL & BDL & BDL & BDL & BDL & BDL & BDL & BDL & BDL & BDL & BDL & BDL & BDL & BDL & BDL & BDL & BDL & BDL & BDL \\
\hline 8 & $\begin{array}{l}\text { Cypermethr } \\
\text { in }\end{array}$ & BDL & BDL & BDL & BDL & BDL & BDL & BDL & BDL & BDL & BDL & BDL & BDL & BDL & BDL & BDL & BDL & BDL & BDL & BDL & BDL \\
\hline 9 & $\begin{array}{l}\text { Deltamethri } \\
\mathrm{n}\end{array}$ & BDL & BDL & BDL & BDL & BDL & BDL & BDL & BDL & BDL & BDL & BDL & BDL & BDL & BDL & BDL & BDL & BDL & BDL & BDL & BDL \\
\hline $\begin{array}{l}1 \\
0\end{array}$ & Fenvalerate & $2(25)$ & $\begin{array}{l}0.0 \\
12\end{array}$ & $\begin{array}{l}0.0 \\
13\end{array}$ & $\begin{array}{l}0.0 \\
03\end{array}$ & $2(25)$ & $\begin{array}{l}0.0 \\
11\end{array}$ & $\begin{array}{l}0.0 \\
53\end{array}$ & $\begin{array}{l}0.0 \\
08\end{array}$ & $\begin{array}{l}1(12 . \\
5)\end{array}$ & BDL & $\begin{array}{l}0.0 \\
22\end{array}$ & $\begin{array}{l}0.0 \\
03\end{array}$ & $2(25)$ & $\begin{array}{l}0.0 \\
11\end{array}$ & $\begin{array}{l}0.0 \\
21\end{array}$ & $\begin{array}{l}0.0 \\
04\end{array}$ & $\begin{array}{l}\text { 1(12. } \\
5)\end{array}$ & BDL & $\begin{array}{l}0.0 \\
23\end{array}$ & $\begin{array}{l}0.0 \\
03\end{array}$ \\
\hline
\end{tabular}


Table 3 Pearson's correlation matrix

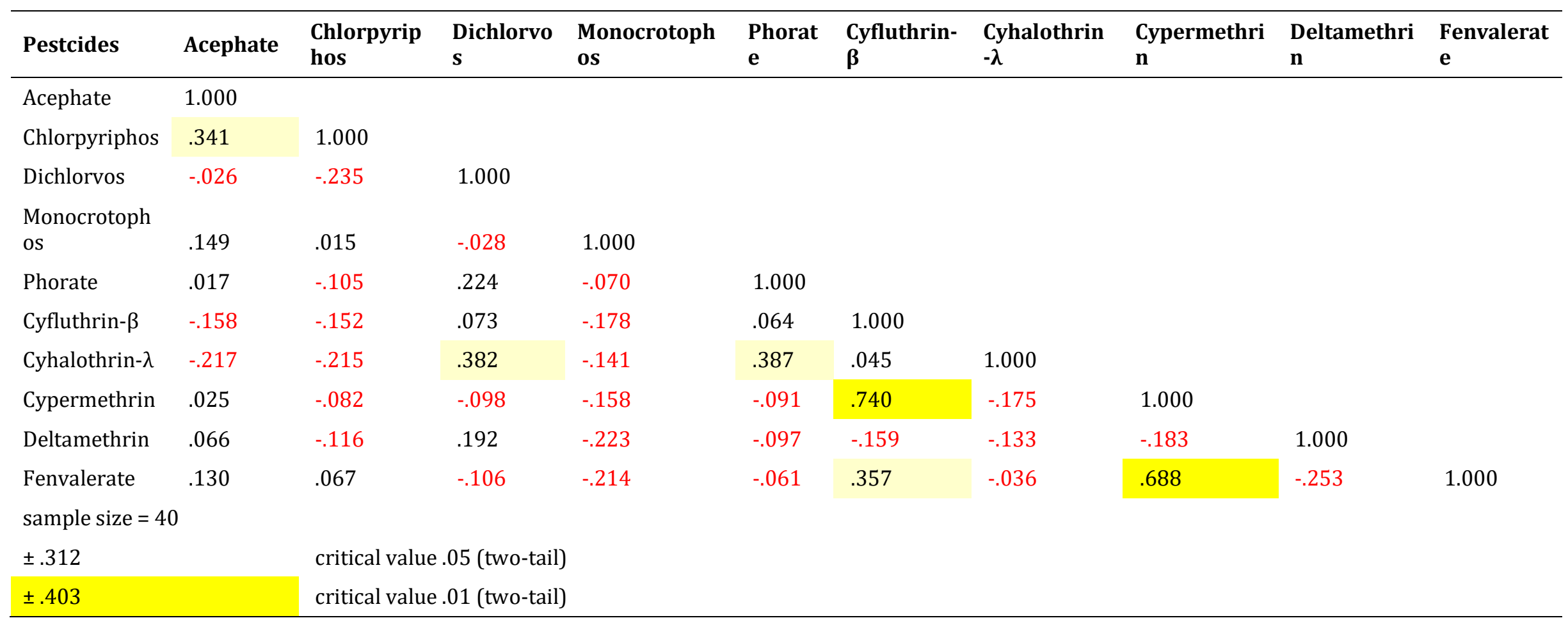




\section{Pesticide residues in carrot}

Variation in acephate, chlorpyriphos, dichlorvos, monocrotophos, phorate, cyfluthrin- $\beta$, cyhalothrin- $\lambda$, cypermethrin, delta methrin and fenvalerate residues in carrot samples are summarized below.

\subsection{Acephate residues}

The Acephate residue concentration in carrot samples varied from 0.088 to $0.095 \mathrm{mg} / \mathrm{kg}$ (mean $=0.023 \mathrm{mg} / \mathrm{kg}$ ) in Bangalore rural, 0.067 to $0.268 \mathrm{mg} / \mathrm{kg}$ (mean $=0.056 \mathrm{mg} / \mathrm{kg}$ ) in Bangalore urban, 0.114 to $0.245 \mathrm{mg} / \mathrm{kg}$ (mean = $0.066 \mathrm{mg} / \mathrm{kg}$ ) in Chikkaballapura and 0.151 to $0.324 \mathrm{mg} / \mathrm{kg}$ (mean $=0.081 \mathrm{mg} / \mathrm{kg}$ ) in Ramanagara district. The sample contamination accounted 25\% in Bangalore rural, 37.5\% each in Bangalore urban, Chikkaballapura and Ramanagara districts. It was not detected in the samples from Kolar and none showed acephate residue above the MRL of $2.0 \mathrm{mg} / \mathrm{kg}$. Nonetheless, the trend of mean concentration of Acephate residue in carrot in different districts is Bangalore urban > Chikkaballapura $>$ Kolar $>$ Ramanagara $>$ Bangalore rural.[13] who evaluated cabbage samples from different local markets of Egypt and found that the acephate residue concentration varied from 0.182 to $0.457 \mathrm{mg} / \mathrm{kg}$. The results of the present investigation are also supported by findings of a similar survey conducted by [14] who reported residue of acephate in the range of $0.05-0.37 \mathrm{mg} / \mathrm{kg}$ in the farmgate samples of cauliflower from Punjab while [15] reported the residue concentration of acephate in fruits and vegetables samples from South America as $0.06-0.028 \mathrm{mg} / \mathrm{kg}$.

\subsection{Chlorpyriphos residues}

Chlorpyriphos residue was not detected in carrot samples from Chikkaballapura and Ramanagara districts. In the samples from Bangalore rural, Bangalore urban and Kolar districts, it ranged from 0.073 to $0.075 \mathrm{mg} / \mathrm{kg}$ (mean = $0.019 \mathrm{mg} / \mathrm{kg}$ ), 0.034 to $0.327 \mathrm{mg} / \mathrm{kg}$ (mean $=0.045 \mathrm{mg} / \mathrm{kg}$ ) and 0.091 to $0.092 \mathrm{mg} / \mathrm{kg}$ (mean $=0.023 \mathrm{mg} / \mathrm{kg}$ ) respectively with $25 \%$ of the sample from each district showing contamination with respect to chlorpyriphos residue. None of the samples had chlorpyriphos residue above the MRL of $0.2 \mathrm{mg} / \mathrm{kg}$ except for $12.5 \%$ of samples from Bangalore urban district. The trend of mean concentration of chlorpyriphos residue in carrot is Bangalore urban $>$ Kolar $>$ Bangalore rural. [16] studied chlorpyrifos residues levels in 309 samples of fruits and vegetables (pineapple, lettuce, cabbage, cucumber and onion) samples sold in Ghanaian markets, with the residue level varying from $0.001-0.062 \mathrm{mg} / \mathrm{kg}$. They also found that chlorpyriphos in pineapple was higher than their respective European Commission MRLs. Mean concentration of chlorpyrifos was reported in egg plant $(24.02 \mu \mathrm{g} / \mathrm{kg})$, cabbage $(10.55 \mu \mathrm{g} / \mathrm{kg})$, cauliflower $(2.85 \mu \mathrm{g} / \mathrm{kg})$, tomato $(178.87 \mu \mathrm{g} / \mathrm{kg})$ and ladyfinger $(2.49 \mu \mathrm{g} / \mathrm{kg})$ from Hyderabad, Andhra Pradesh, India $[17,18]$. These results are also in fair agreement with our findings.

\subsection{Dichlorvos residues}

In Bangalore rural, Bangalore urban, Chikkaballapura and Kolar districts, the dichlorvos residue in carrot samples respectively varied from BDL to $0.013 \mathrm{mg} / \mathrm{kg}$ (mean $=0.002 \mathrm{mg} / \mathrm{kg}$ ), BDL to $0.027 \mathrm{mg} / \mathrm{kg}$ (mean $=0.003 \mathrm{mg} / \mathrm{kg}$ ), BDL to $0.011 \mathrm{mg} / \mathrm{kg}$ (mean $=0.001 \mathrm{mg} / \mathrm{kg}$ ) and BDL to $0.014 \mathrm{mg} / \mathrm{kg}$ (mean $=0.002 \mathrm{mg} / \mathrm{kg})$ with $12.5 \%$ sample contamination in each district. Dichlorvos residue in none of samples crossed the MRL value of $0.15 \mathrm{mg} / \mathrm{kg}$ while it was not detected in the samples from Ramanagara district. The trend of mean concentration of dichlorvos residue in carrot is Bangalore urban > Bangalore rural > Chikkaballapura. [19] who reported dichlorvos residue concentration ranging from $0.004-$ $0.022 \mathrm{mg} / \mathrm{kg}$ in cabbage, cauliflower, pea grains, brinjal, tomato, potato and green chilly samples collected from wholesale markets of Hisar, Haryana.

\subsection{Phorate residues}

In Bangalore rural, the concentration of phorate residue in carrot samples varied from 0.035 to $0.072 \mathrm{mg} / \mathrm{kg}$ (mean = $0.019 \mathrm{mg} / \mathrm{kg}$ ) with $37.5 \%$ of samples contaminated and in Bangalore urban, it ranged from 0.036 to $0.078 \mathrm{mg} / \mathrm{kg}$ (mean $=0.014 \mathrm{mg} / \mathrm{kg}$ ) with $25 \%$ of samples contamination. In Chikkaballapura district, it ranged from 0.044 to $0.078 \mathrm{mg} / \mathrm{kg}$ $($ mean $=0.021 \mathrm{mg} / \mathrm{kg})$ with $37.5 \%$ of sample contamination while it varied from 0.033 to $0.081 \mathrm{mg} / \mathrm{kg}$ (mean = $0.028 \mathrm{mg} / \mathrm{kg}$ ) with $37.5 \%$ of samples contamination in Kolar district. Phorate residue values exceeded the MRL value of $0.05 \mathrm{mg} / \mathrm{kg}$ in $12.5 \%$ of samples collected from these districts. Contrast to this, in Ramanagara district, it ranged from 0.038 to $0.041 \mathrm{mg} / \mathrm{kg}$ (mean $=0.02 \mathrm{mg} / \mathrm{kg}$ ) with $25 \%$ of sample contamination and none of samples having residue above the MRL. The trend of mean concentration of phorate residue in carrot in different districts is Kolar > Chikkaballapura $>$ Ramanagara $>$ Bangalore rural $>$ Bangalore urban. [20] who revealed the presence of phorate in Shanghai green $(0.0257 \mu \mathrm{g} / \mathrm{g})$ and Chinese cabbage $(0.0398 \mu \mathrm{g} / \mathrm{g})$ from Nanjing, China. The present investigation results are also endorsed by findings of [21] who reported phorate residues in fruits and vegetables which vary from BDL to $0.405 \mathrm{mg} / \mathrm{kg}$ from Xiamen, China.

\subsection{Cyfluthrin- $\beta$ residues}


In Bangalore urban, the concentration of cyfluthrin- $\beta$ residue in carrot samples is BDL to $0.043 \mathrm{mg} / \mathrm{kg}(\mathrm{mean}=$ $0.005 \mathrm{mg} / \mathrm{kg}$ ) with $12.5 \%$ of samples showing contamination with cyfluthrin- $\beta$, but none of the samples crossed the MRL value of $3.0 \mathrm{mg} / \mathrm{kg}$. It is not detected in the carrot samples from Bangalore rural, Chikkaballapura, Kolar and Ramanagara districts.

\subsection{Fenvalerate residues}

The concentration of fenvalerate residue in carrot varied from 0.012 to $0.013 \mathrm{mg} / \mathrm{kg}$ (mean $=0.003 \mathrm{mg} / \mathrm{kg}$ ) with $25 \%$ of samples contamination in Bangalore rural, 0.011 to $0.053 \mathrm{mg} / \mathrm{kg}$ (mean $=0.008 \mathrm{mg} / \mathrm{kg}$ ) with $25 \%$ of samples contamination in Bangalore urban, BDL to $0.022 \mathrm{mg} / \mathrm{kg}$ (mean $=0.003 \mathrm{mg} / \mathrm{kg}$ ) with $12.5 \%$ of samples in Chikkaballapura, 0.011 to $0.021 \mathrm{mg} / \mathrm{kg}$ (mean $=0.004 \mathrm{mg} / \mathrm{kg}$ ) with $25 \%$ of samples contamination in Kolar and BDL to $0.023 \mathrm{mg} / \mathrm{kg}$ (mean $=0.003 \mathrm{mg} / \mathrm{kg}$ ) and $12.5 \%$ of samples in Ramanagara districts. None of the samples having fenvalerate concentration was higher than the MRL value of $1.0 \mathrm{mg} / \mathrm{kg}$. The trend of mean concentration of fenvalerate residue in carrot in different districts is Bangalore urban $>$ Kolar $>$ Chikkaballapura = Ramanagara = Bangalore rural. [22] in carrot and onion markets samples from Kumasi ranged from 0.004-0.008mg/kg (mean: 0.006mg/kg) and 0.031$0.042 \mathrm{mg} / \mathrm{kg}$ (mean: $0.037 \mathrm{mg} / \mathrm{kg}$ ) respectively. The results are also satisfactory with the findings of [23] who reported the presence of fenvalerate in the range of $0.061-0.07 \mathrm{mg} / \mathrm{kg}$ in vegetable samples like green pepper, white onion, tomato, lettuce, green onion, potato and saladette tomato produced in Sonora, Mexico.

\subsection{Monocrotophos, Cyhalothrin- $\lambda$, Cypermethrin, Deltamethrin residues}

The monocrotophos, cyhalothrin- $\lambda$, cypermethrin and deltamethrin residues are below the detectable level in carrot samples from all the five districts [24] reported $9.5 \%$ ber fruit samples contained $0.030 \mu \mathrm{g} / \mathrm{g}$ monocrotophos and $14.2 \%$ of guava fruit samples had detectable amount of monocrotophos. Similarly, a study by [25] revealed the presence of monocrotophos in the range of $0.001-0.044 \mathrm{mg} / \mathrm{kg}$ in vegetable samples (viz., brinjal, cucumber, okra, ridge gourd and tomato) collected from Andhra Pradesh, India.

\subsection{Pearson's correlation matrix}

The Pearson's correlation matrix was carried out using SPSS as it describes the interrelationship among various variables. This procedure calculates any of a wide variety of statistics measuring either similarities or dissimilarities (distances), either between pairs of variables or between pairs of cases. These similarity or distance measures can then be used with other procedures, such as factor analysis, cluster analysis, or multi-dimensional scaling, to help analyze complex data sets. The correlation matrix of analyzed pesticide residues parameters are presented in Table3. Cyfluthrin- $\beta$ residue showed strong positive correlation with cypermethrin residue $(r=0.740)$ and in turn cypermethrin with fenvalerate $(\mathrm{r}=0.688)$, both at 0.01 level of significance. Moderate positive correlation existed between acephate and chlorpyriphos $(\mathrm{r}=0.341)$, dichlorvos and cyhalothrin- $\lambda(\mathrm{r}=0.382)$, phorate and cyhalothrin- $\lambda$ $(r=0.387)$ and, cyfluthrin- $\beta$ and fenvalerate $(r=0.357)$ at 0.05 level of significance. Correlations between other pesticide residues were insignificant both at 0.01 and 0.05 levels of significance.

\section{Conclusion}

Carrot samples that were found to be contaminated with pesticide residues accounted for 27.5\% acephate, $15 \%$ chlorpyriphos, $10 \%$ dichlorvos, $32.5 \%$ phorate, $5 \%$ cyfluthrin- $\beta$ and $20 \%$ fenvalerate. Multimedia awareness activities in local language should be massively conducted on the dangers posed by pesticides contamination in the food.Proper legislations on handling of pesticide should be introduced and practiced. Measures must be enforced to stop the use of forbidden pesticides. Integrated pest management or Integrated Crop management to be adopted in order to decrease amount of the pesticide and improve human health.

\section{Compliance with ethical standards}

\section{Acknowledgments}

The authors are highly indebted to University Grants Commission (UGC), New Delhi for providing the assistantship and college authorities for necessary infrastructure and encouragement.

\section{Disclosure of conflict of interest}


Authors have declared that no conflict of interests exists.

\section{References}

[1] Krishnamurthy CR. (1984). Pesticide residues in food and biological tissues. Indian National Science Academy, New Delhi.

[2] Mauskar JM. (2007). Comprehensive Industry Documents Series (COINDS). Central Pollution Control Board Ministry of Environment and Forests.

[3] Hammerton JL and Reid ED. (1985). Agrochemicals in St. Lucia, an overview, In CARDI, Risk Assessment of Agrochemicals in the Eastern Caribbean. Proceedings of a CARDI/UNESCA, MAB workshop, 16-38.

[4] Sharma RK. (2008). Management of Insect pests in vegetables. Crop care, 34(2), 67- 67.3.

[5] Pandey UB. (2004). Development programmes and policies for accelerated production of vegetables in India. In Food Security and Vegetables - A Global Perspective. Agricultural Science Foundation, Bangalore, 281-303.

[6] Bose TK and Som MG. (1986). Vegetable crops in India, Naya Prakashan, Calcutta, 32-67.

[7] Karanth NGK. (2002). Challenges of Limiting Pesticide Residues in Fresh Vegetables: The Indian Experience. Proceedings of the International Workshop, Montpellier, France, 1-13.

[8] Agnihotri NP. (1999). Pesticide safety evaluation and monitoring, All India Coordinated Research Project on Pesticide Residues Division of Agricultural Chemicals, Indian Agricultural Research Institute, New Delhi, 132142.

[9] AOAC. (2000). Official methods of analysis of the association of official analytical chemists, 17th ed. AOAC International, Maryland, USA.

[10] Harry M and Pylypiw JR. (1993). Rapid gas chromatographic method for the multi-residue screening of fruits and vegetables for organochlorine and organophosphate pesticides. J. AOAC, 76 (6), 1369-1374.

[11] Michel AN and Steven JL. (2003). Fast and easy multiresidue method employing acetonitrile extraction partitioning and "Dispersive solid-phase extraction" for the determination pf pesticide residues in produce. J. AOAC, 86 (2), 412-432.

[12] Anna S, Luciana B and Mirella B. (2004). Application of liquid chromatography with electrospray tandem mass spectrometry to the determination of a new generation of pesticides in processed fruits and vegetables, journal of Chromatography, 1036, 161 -169.

[13] Mohammed MZ and Mohammed AS. [2009].Synthesis and some properties of fluorinated cationic surfactants. Journal of surfactants and detergents 12 [4], 345-349.

[14] Kousik Mandal and Balwinder Singh. (2010). Magnitude and frequency of pesticide residues in farmgate samples of cauliflower in Punjab, India. Bulletin of Environment Contamination Toxicology, (85), 423-426.

[15] Hjorth K, Johansen K, Holen B, Andersson A, Christensen HB, Siivinen K and Toome M. (2011). Pesticide residues in fruits and vegetables from South America - A Nordic project. Food Control, (22), 1701-1706.

[16] Crentsil Kofi B, Jacob A, Daniel AA, Juliana B and Stephen BA. (2012). Contamination levels of selected organochlorine and organophosphorus pesticides in Ghanaian fruits and vegetables. Emirates Journal of Food and Agriculture, 24 (4), 293-301.

[17] Sukesh NS, Vishnu Vardhana RM and Vasudev K. (2012). Distribution of pesticides in different commonly used vegetables from Hyderabad, India. Food Research International, 45, 161-169.

[18] Ramesh HL. (2015). Analysis of fruit and vegetables for pesticide residues using gas chromatograph. Indian Journal of Agriculture Research, 5(3), 526-529.

[19] Beena K, Kumar R, Madan VK, Rajvir S, Jagdeep S and Kathpal TS. (2003). Magnitude of pesticidal contamination in winter vegetables from Hisar, Haryana, Environment Monitoring and assessment, 87, 311-318.

[20] Ligang W, Yongchao L and Xin J. (2008). Analysis of eight organophosphorus pesticide residues in fresh vegetables retailed in agricultural product markets of Nanjing, China. Bulletin of Environment Contamination Toxicology, (81), 377-382. 
[21] Chen C, Yongzhong Q, Qiong C, Chuanjiang T, Chuanyong Li and Yun Li. (2011). Evaluation of pesticide residues in fruits and vegetables from Xiamen, China. Food Control, (22), 1114-1120

[22] Crentsil KB, Archibold B, Dzifa D, Jacob A and Anita OT. (2011). Monitoring of pesticide residues in fruits and vegetables and related Health risk assessment in Kumasi metropolis, Ghana Research Journal of Environment and Earth sciences, 3(6), 761-771.

[23] Maria L, Aldana-Madrid, Ana I, Valenzuela-Quintanar, Maria I, Silveira-Gramont, Guillermo Rodriguez-Olibarria, Patricia Grajeda-Cota, Fabiola G and Zuno-Floriano Marion GM. (2011).Residual pyrethroids in fresh horticultural products in Sonora, Mexico. Bulletin of Environment Contamination Toxicology, (87), $436-439$.

[24] Beena Kumari, Madan VK and Kathpal TS. (2006). Monitoring of pesticide residues in fruits. Environment Monitoring and assessment, 123, 407-412.

[25] Ranga Rao GV, Sahrawat, KL, Srinivasa Rao, Binitha Das, Kirankumar Reddy K, Bharath, BS, Rameshwar Rao V, Murthy, KVS and Wani SP. (2009). Insecticide residues in vegetable crops grown in Kothapalli watershed, Andhra Pradesh, India: A case study. Indian Journal of Dry land Agriculture and Research Development, 24 (2), 21-27.

\section{How to cite this article}

Ananda G, SR Kesava RA and Ramesh HL. (2020). Analysis of pesticide residues in carrot retailed in vegetable markets in five districts of Karnataka, India. GSC Biological and Pharmaceutical Sciences, 10(3), 27-38. 